\title{
LAWSONE: Natural Colorant in Fashion Technology $\&$ Textile Engineering
}

\author{
Sharad Patil* and Divyang Panchal \\ Department of Chemistry, Uka Tarsadia University, India
}

Submission: April 19, 2018; Published: May 14, 2018

*Corresponding author: Sharad Patil, Department of Chemistry, Uka Tarsadia University, Bardoli, Gujarat, India, Email: sharad.omd.patil@gmail.com

\begin{abstract}
Lawsone (2-hydroxynaphthalene-1, 4-dione) is a natural colorant which shows significant fashionable and textile activity. Traditionally in India, mehandi is applied to hands and feet. Henna symbolizes fertility. Its use became popular in India because of its cooling effect in the hot Indian summers.
\end{abstract}

Keywords: Natural colorant; Henna; Lawsone; Fashion technology; Textile

\section{Introduction}

Love for colour is a natural instinct. Every individual has his own choice and liking for colour and nature manifests itself during a wide spectrum of colors. Nature has always dominated over synthetic or artificial, from the beginning of this world as nature was the only option for human being then, and now with advantageous characteristics of naturally derived materials over synthetics giving them priority. Color has always played an important role in the formation of different cultures of human being all over the world. It affects every moment of our lives, strongly influencing the clothes we wear, the furnishings in our homes. In the past, painters had used natural dyes extracted from plants, insects, molluscs and minerals for their paintings. Natural colorants were used in fabrics, as well as in cosmetic industry.

Henna, 2-hydroxy-1, 4 naphthoquinone (lawsone) is a wellknown compound occurred in the henna plant leaves, Lawsoneia inermis. Henna is a prominent natural colorant plant belonging to the family Lythraceae and is cultivated in India, Pakistan, Egypt, Yemen, Iran, and Afghanistan [1]. Henna has been used for more than 4,000 years, not only as a hair dye but also as a body paint and tattoo dye. Today, semi-permanent hair dyes containing henna as well as its pure dye ingredient, naphthoquinone is widely used and have become increasingly popular due to their natural origin [2-3].

The traditional use of Lawsone containing extracts from henna leaves is dying of hair and nails as well as traditional paintings on skin [4]. The natural colorant Lawsone can also be used for dyeing textile materials, e.g. wool and silk, where orange to brown colors are obtained [5]. The extracted dyestuff can be applied as direct dye or in combination with an alum mordant. The highest uptake of both henna extracts and Lawsone was found for wool to occur at $\mathrm{pH}$ 3. The affinity of the rather small molecule is mainly attributed to ion dipole forces between the polar groups of the dye and protonated amino groups of the wool [6]. After chroming of Lawsone dyeing causes a shift in shade, which is attributed to a chromium complex formation. Also cotton substrates have been dyed with henna extracts using different mordants [7]. Thermodynamic studies of the dyeing behavior of Lawsone on wool, silk and polyester indicated aggregation of Lawsone molecules in solution and also in the dyed substrate [8]. Lawsone showed the highest affinity to polyester, followed by polyamide, which is explained by the chemical nature of Lawsone, which is similar to a disperse dye [6]. The application of henna extracts has also been investigated for dyeing of cellulose-triacetate [9]. The simple application procedure of henna permits the use of such dyes in combination with other synthetic dyes, e.g. reactive dyes [10]. Another application of henna pigment is in paints [11]. Henna extracts have even been studied as a corrosion prevention agent for metals, e.g. steel, nickel, zinc and aluminium $[12,13]$.

\section{Conclusion}

Natural dyes are not only having dyeing property but also having the wide range of medicinal and high-tech applications. Now-a-days, providentially, there is increasing awareness among 
people towards natural dyes and colorants yielding plants. Due to their non-toxic properties, fewer side effects, more medicinal values, natural dyes are used in day-to-day food products, in pharmaceutical industry and high-tech applications. Henna, 2-hydroxy-1, 4 naphthoquinone (lawsone) is widely used in the cosmetic industry and textile industry as dyeing agent. It consists of fresh or dried leaves of the plant Lawsoneia inermis $L$. In India henna plant has been used as herbal dye to decorate hands, feet, hair etc. Henna is natural herbal dye and it tends to be softer. Henna has been used cosmetically and medicinally for over 9,000years.

\section{Acknowledgement}

The authors would like to express their gratitude to Uka Tarsadia University, India.

\section{References}

1. Shahid I, Faqeer M (2015) Natural Colorants in the Presence of Anchors So-Called Mordants as Promising Coloring and Antimicrobial Agents for Textile Materials. ACS Sustainable Chem Eng 3(10): 2361-2375.

2. Siddiqui BS, Kardar MN, Ali T, Khan S (2003) Two New and a Known Compound from Lawsonia inermis. Helv Chim Acta 86(6): 2164-2169.

3. Kot M, Karcz W, Zaborska W (2010) 5-Hydroxy-1,4-naphthoquinone (juglone) and 2-hydroxy-1,4-naphthoquinone (lawsone) influence on jack bean urease activity: Elucidation of the difference in inhibition activity. Bioorganic Chemistry 38(3): 132-137.

4. Spurles PLK (2006) This is Different, this is the Plaza: Space, Gender, and Tactics in the Work of Moroccan Tourist Sector Henna Artisans. Research in Economic Anthropology 25: 99-123.

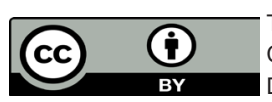

This work is licensed under Creative

Commons Attribution 4.0 Licens

DOI:10.19080/CTFTTE.2018.03.555622
5. Agarwal A, Garg A, Gupta KC (1992) Development of suitable dyeing process for dyeing of wool with natural dye henna. Colourage 39(10): 43-45.

6. Badri BM, Burkinshaw SM (1993) Dyeing of wool and nylon 6.6 with Henna and Lawsone. Dyes and Pigments 22(1): 15-25.

7. Ali S, Hussain T, Nawaz R (2009) Optimization of alkaline extraction of natural dye from Henna leaves and its dyeing on cotton by exhaust method. Journal of Cleaner Production 17(1): 61-66.

8. Gupta DB, Gulrajani ML (1994) Kinetic and thermodynamic studies on 2-hydroxy-1, 4-naphthoquinone (lawsone). J Soc Dyers Colour 110(3): $112-115$.

9. Teli MD, Adivarekar RV, Shah R, Sabale AG (2004) Dyeing of cellulose triacetate with natural colourants. Journal of the Textile Association 64(6): 285-294.

10. Miller NJ, Simpson J, Candeias LP, Bramley BM, Rice-Evans CA (1996) Antioxidant activities of carotenes and xanthophylls. FEBS J 384: $240-$ 242.

11. Abidin ZHZ, Taha RM, Puteh R, Arof AK (2006) Characteristics of Paints Prepared from Lawsonia Pigment and Dammar from Dipterocarpus Grandifoleus. Materials Science Forum 517: 290-293.

12. Petkewich (2006) Rapid screening and optimization of enzymatic activity, along with available, easy-to-use enzymes, are making biocatalysis a handy tool for chiral synthesis. R Chem Eng News 84: 28.

13. El-Etre AY, Abdallah M, El-Tantawy ZE (2005) Corrosion inhibition of some metals using lawsonia extract. Corrosion Science 47(2): 385-395.

\section{Your next submission with Juniper Publishers will reach you the below assets}

- Quality Editorial service

- Swift Peer Review

- Reprints availability

- E-prints Service

- Manuscript Podcast for convenient understanding

- Global attainment for your research

- Manuscript accessibility in different formats

( Pdf, E-pub, Full Text, Audio)

- Unceasing customer service

Track the below URL for one-step submission https://juniperpublishers.com/online-submission.php 